\title{
Fraudulent Financial Reporting Based of Fraud Diamond Theory: A Study of the Banking Sector in Indonesia
}

\author{
Tarmizi Achmad ${ }^{1}$ and Imang Dapit Pamungkas ${ }^{2}$ \\ ${ }^{1)}$ Diponegoro University, Semarang and ${ }^{2)}$ University of Dian Nuswantoro, Semarang \\ Email: t achmad@yahoo.com.au and imangdapit.pamungkas@dsn.dinus.ac.id
}

\author{
ARTICLE INFO \\ Article History: \\ Received 22 May 2018 \\ Revised 15 June 2018 \\ Accepted 15 July 2018 \\ JEL Classification \\ M40, M42 \\ Keywords: \\ Fraudulent \\ Reporting, \\ Fraud Diamond, and \\ Capability
}

\section{ABSTRACT}

The research aims to analyse whether external pressure, financial stability, financial targets, ineffective monitoring, rationalization and capability effect on fraudulent financial reporting. The population this study is banking company listed on the Indonesia Sctock Exchange with a total sample of 87 banking companies in 2011-2016. Based on the results of research using regression analysis, only external variables of incentive and financial targets have a positive effect on fraudulent financial reporting. Meanwhile, financial stability and capability have a negative impact on fraudulent financial reporting. Further, other variables such as ineffective monitoring and rationalization do not affect fraudulent financial reporting.

\section{INTRODUCTION}

The large number of financial scandals has provided further evidence of audit failure that has serious consequences for the business community, especially investors where fraudulent financial reporting carries the greatest losses (ACFE, 2016). Based on the large number of fraudulent financial reporting it is one reason to analyze how to prevent and reduce fraudulent financial reporting. Manipulation of financial reporting has increased from year to year. When financial reporting contains manipulation, these elements do not present the actual state (Spathis, 2002).

Accountants as professions who carry the public trust have a great responsibility to detect and report fraud and/or material misstatements that were discovered before they developed into accounting scandals that bring about losses in material form (Skousen et al., 2009). Nevertheless, with the emergence of differences between expectations related to the roles and responsibilities of the auditor with investors, creditors, and the public with the auditor profession causes the fraud of audited financial reporting to be regarded as a form of auditor negligence (Chye and Hian, 1998). In response to an expectation gap in dealing with fraud detection weaknesses, users of financial reporting are expected to identify more carefully and detail in assessing a company's picture. The identification of the occurrence of fraud is important because fraud often results in losses to the investors of the company.

The studies above have provided evidence of the role of investors that is very important in describing a company's financial reporting for investment. Investors can detect financial reporting through financial ratios and other enterprise information that support accuracy in investment decision making. The existence of research results show that 
investors can detect fraud by looking at financial ratios in published financial statements (Ravisankar, 2011). This proves that there are still things that can be explored in the detection problem of financial reporting engineering. In contrast to previous studies that has been conducted in developed countries. This research takes the case of Indonesia as a developing country. This study was motivated by the research of Spathis, et al. (2002) and Zhang and Guan (2008) using perspective fraud diamond.

A re-examination of a research result with a more specific condition is also supported by Otley's et al. (1994) suggests that replication under different conditions would place confidence in a prior research result at a better level. Financial ratio analysis is not only important for the management but also important for the external company. For external parties, financial ratio analysis is important to obtain general description of the progress of financial performance in the company. The existence of information regarding the progress of financial performance in the company, they can decide whether to continue investing their funds in the company. The benefits of financial factor analysis are to know the existence of strength and financial weakness of previous years. By comparing the ratio of financial ratios with the standard set other benefits will be obtained that can be known whether in certain financial aspects of the company is above standards or below the standard.

Accounting information in financial statements is very important for business people as investors in decision making. In order to be useful, the information must be relevant to meet the needs of the user in the decision making process. Information is said to be relevant if it can influence the economic decisions of the users by assisting them in evaluating past, present, or future events, affirming or correcting their past evaluation results. To be able to interpret accounting information relevant to the purpose and interests of the wearer, a set of analytical techniques has developed based on published financial statements (Kirkos et al., 2007).

The impacts and consequences of fraudulent financial reporting are inevitable. The company will suffer significant losses because of it. Accounting fraud is usually triggered by a company that wants its financial statements to look good. In addition, the company also wants to reduce the perception in the eyes of potential investors that his company is at risk. Company shares may be rated higher if investors judge that the company has a low risk level, because they will not worry the company will go bankrupt. In order to create such a good perception, some companies use strategy by fraud. Accounting fraud cases are common, as in the banking sector (Owolabi, 2010).

Banking companies have different characteristics with other companies. Banking companies have stricter regulations than in other corporate sectors. In the banking world, although using high technology, still susceptible to fraud. Several fraud cases have occurred in the banking sector, such as: giving credit and fictitious guarantees at Bank International Indonesia (BII) on January 31, 2011, involving BII account officer Branch Pangeran Jayakarta. the total loss that occurred was amounting to IDR 3.6 billion. Next, theft is carried out by five suspects related to the withdrawal of funds from Bank Mandiri customers services with a total loss of IDR 18 billion. Furthermore, the head of Danamon Bank teller Branch Danamon Tower Repeated cash withdrawals showing customer funds of IDR 1.9 billion and USD 110,000 revealed on March 9, 2015. The rise in various cases in an accounting scandal causing various parties to speculate that fraudulent financial reporting was carried out by management. With the occurrence of this phenomenon makes researchers interested to learn more about the factors to know and prevent fraudulent financial reporting. 
Fraud Diamond theory is used to find out the causes of fraud, elements of diamond fraud, namely incentive, opportunity, rationalization and capability. Incentive is an impulse to commit fraud. Incentive can be in the form of lifestyle, economic demands, including finance and non-finance. incentive, namely an impulse or goal to be achieved, but it is facilitated by the inability to get it so that someone makes fraud (Abbasi et al., 2012). SAS No. 99 explained that there are several conditions that occur at incentive which can cause fraud triggers, such conditions as external pressure, financial stability and financial targets (Rukmawati, 2011).

Skousen et al. (2011) found that companies that have high debt ratios are motivated to manipulate income. Companies prefer to do fraudulent financial reporting if they have opportunities by earning management so that their performance is seen by shareholders. Furthermore, Dorminey (2010) argues that when the liquidity company is low, it can motivate management to commit fraudulent financial reporting. Managers must be able to do their best in achieving planned targets. The performance assessment is used to formulate and raise bonuses. Furthermore, if the company's financial targets rise, it makes it possible for fraudulent financial reporting such as conducting management learning. Return on assets is a ratio to determine the ability of a company to obtain its net profit by using company asset.

Companies with low governance and few audit committees dominated by insiders tend to have high fraud (Dechow et al., 2012). This opinion is the same as stated by Rasha and Andrew (2012) who concluded that a high level of fraud can occur when the concentration of power is owned by an insider, the ethics of supervision by the board of commissioners is not effective, causing very potential fraud. This is due to a lack of supervision from external parties. Furthermore, this study shows that auditors in large companies have the ability to detect fraud that is better because public accounting firms have a big goal.

Based on this background, the purposes of this study are to know and obtain empirical evidence: (1) to know and obtain emperical evidence external pressure have a significant positive effect on fraudulent financial statements; (2) To know and obtain empirical emperical evidence whether financial stability negatively affects fraudulent financial reporting. (3) To know and obtain empirical evidence whether financial targets have a significant negative effect on fraudulent financial reporting. (4) To know and obtain empirical evidence whether ineffective mentoring negatively affects fraudulent financial reporting. (5) To know and obtain empirical evidence whether rationalization negatively affects fraudulent financial reporting. (6) To know and obtain empirical evidence whether the Capability to negatively affect fraudulent financial reporting.

\section{LITERATURE REVIEW AND HYPOTHESES DEVELOPMENT \\ Fraud Diamond Theory}

Fraud Diamond Theory is a theory that explains the causes of fraud. The initial concept of Fraud Diamond was first introduced by Wolfe and Hermanson (2004). Fraud Diamond describes four factors that exist in every fraudulent situation, such as Incentive, that is an external need that makes people do wrong; Opportunities, situations that support various frauds; Rationalization, namely justification of the behavior of certain parties who commit fraud; Capability that is special skill or capability to commit fraud (Wolfe and Hermanson, 2004). Deficiencies that occur cannot occur without the person having individual abilities. even though there are opportunities that open the way to fraud, one must have the capability to see things as an opportunity to take advantage of fraud. 


\section{Fraudulent Financial Reporting}

The Association of Certified Fraud Examiners (ACFE) is the largest anti-fraud association in the world as well as providing anti-fraud training and education. In addition, ACFE also explains that fraud is an unlawful act carried out intentionally for certain purposes (manipulation) or give false reports to other parties) carried out by people from inside who are not in an organization to gain their own benefit or organization directly or indirectly directly harm the other party (Europe, 2012). According to the Association of Indonesian Accountants, accounting fraud is: fraudulent financial statements can be in the form of misrepresentation of the financial statements by deliberate means, do not make disclosures and actually eliminate the number of certain accounts in order to trick users of financial statements. Furthermore, fraud is caused by theft or embezzlement of assets or making financial statements that are not in accordance with generally accepted accounting principles in Indonesia.

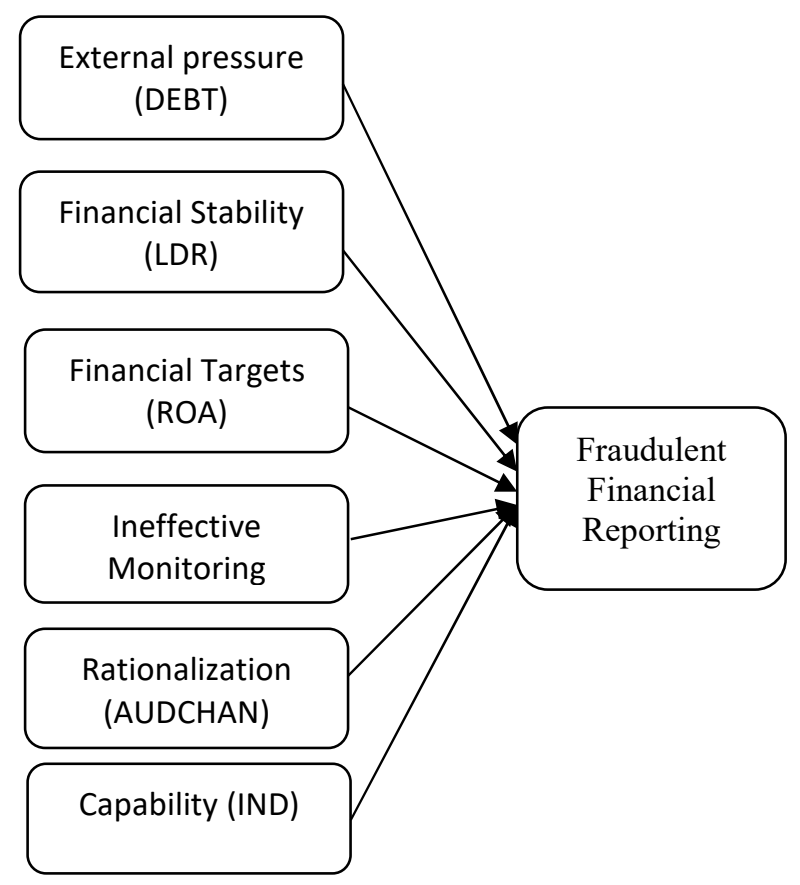

Figure 1. Conceptual Framework

\section{External Pressure on Fraudulent Financial Reporting}

Companies often get incentive from outside parties. One of the most frequent incentive comes from the management of the company, namely the need to obtain additional debt/ external funding sources to be competitive, such as research and development of financing and capital expenditures. Companies with high debt ratios lead to customers manipulate the driven earnings. Companies tend to commit fraudulent financial reporting when there is an opportunity to conduct earnings management in the household to show good performance to the shareholders.

Managers can also make changes to financial statements for the needs to in accordance with the completeness of debt. The statement means that the level of debt if it is higher indicates an increase in fraudulent financial reporting. This is also conveyed by Dechow et al., (2012) and Amara et al., (2013) in the results of their study finding a positive effect on the level of debt with the possibility of fraudulent financial reporting. The high debt ratio has a tendency towards fraudulent financial reporting. So, the hypothesis of this study is:

H1: External pressure (DEBT) has positive effect on fraudulent financial reporting

\section{Financial Stability on Fraudulent Financial Reporting}

According SAS 99, there is incentive on managers to Fraudulent financial reporting if there is threatened financial stability due to economic, industrial or entity operating situations (Skousen et al., 2011). Financial stability is defined as an ability that the company has in completing obligations in the short term of the company (liquidity) is one to see the incentive. Liquidity can be calculated by means of working capital goods, namely assets compared to current liabilities. Liquidity for this research proxy with Loan to Deposit (LDR) is the result of a comparison of total 
loans and third party funds originating from activities carried out by the bank.

The regulation of the finance minister No.12 / 19 / PBI in 2010 clearly explained that loan to deposit measures the ratio loan amount compared to third party funds. LDR banks can be said to be healthy when the limit is $78 \%-100 \%$. This ratio will show the Bank's ability to channel funds originating come from the general public such as savings, current accounts and so forth immediate Liabilities in the form of Credit. When the higher the LDR ratio, the lower the bank's liquidity ratio will be. Managers can act in certain ways when the company experiences bad performance in convincing shareholders that the condition of the company that is going to be healthy so managers will commit fraudulent financial reporting. Companies with a problematic level of liquidity have a tendency to be higher in fraudulent financial reporting compared to companies that have lower liquidity problems. With this argument, we conclude that the hypothesis in this study is:

H2: Financial Stability (LDR) has a significant negative effect on fraudulent financial reporting.

\section{Financial Target on Fraudulent Financial Reporting \\ Company managers in company} activities are expected to do the company with the best performance to realize the previous targets. Skousen et al., (2011) explained that in measuring the effectiveness of a company that is by using assets in generating profits. Return on assets is the company's financial ratio related to the potential profit of measuring the company's strength to produce profits or also profits at the level of income, assets and specific stock capital. This ratio can also measure how efficient a company is in managing its assets to generate profits during a period. With the higher ROA target, companies can generate potential earnings management by manipulating or fraudulent financial reporting. If the company experiences a low profit, it will encourage the company/ management to commit fraud by making misstatements or markups and disclosing non-actual financial statements. Amara et al., (2013) clearly stated that companies with low financial stability tend to have fraudulent financial reporting. Thus, the hypothesis in this study are:

H3: Financial stability (LDR) has a significant negative effect on fraudulent financial reporting

\section{Ineffective Monitoring on Fraudulent Financial Reporting.}

According to SAS No. 99, ineffective monitoring is a condition in a company that does not have good internal monitoring. This situation is influenced by management without the control of directors, board of directors, audit committees that are not effective against internal control and financial reporting. Avoid the practice of internal fraud company, a supervisory unit is needed which is able to monitor the road company. Widespread accounting scandals and the the occurrence of fraud is a result of a weak supervision system done by the company that has give opportunity to someone to act in accordance with interests his personality. With supervision which is not effective, management will feel not closely monitored and increasingly free to find ways to maximize his personal benefits (Rahmanti, 2013).

Ineffective monitoring is proxy audit quality. Audit quality is related to how well a job is completed compared to predetermined criteria. Audit quality is all probability where the auditor at the time of auditing the financial statements of clients can find violations, where in carrying out these tasks the auditor is guided by auditing standards and relevant public accountant's code of ethics. Audit quality is an assessment by market where there is a possibility that the auditor will provide findings regarding a 
violation in the client's accounting system; and violations in the recording (DeAngelo, 1981). Smaili et al., (2009) and Lennox and Pittman (2010) explain that BIG4 external auditors tend to detect better fraud. This is because companies with large public accounting offices also have more serious supervision, one of which is to maintain the reputation of the accounting firm. Luhgiatno (2010) states that "auditors who have better quality tend not to accept accounting methods that are unclear and more capable of detecting errors and fraud. The hypothesis in this study are:

H4: Ineffective monitoring (AUD) has negative effect on fraudulent financial reporting

\section{Rationalization on Fraudulent Financial Reporting}

Rationalization is the justification of oneself or a reason for someone in wrongdoing and rationalzation is an important element in fraud (Abbasi et al., 2012). This study uses proxy external auditor changes in the company. Substitution of external auditors can replace fraudulent financial reporting. The more often the company makes changes to external auditors, the higher the chances of companies fraudulent financial reporting. Lou and Wang (2009) state the change in external auditors to reduce the detection of fraudulent financial reporting.

Companies often change external auditors tend to fraud because of auditor changes, companies that commit fraud will most likely not be known if audited by a new auditor. Baik et al., (2011) state that companies can change auditors to reduce the possibility of detecting fraudulent financial reporting. Therefore, companies that make mandatory audit changes tend not to commit fraudulent financial reporting.

Rationalization on companies can be accepted with auditor turnover cycles, audit opinions obtained by the company, and total accrual conditions divided by total increases (Skousen, 2008). The variables used in this study are auditor changes. Repayment of Suspended farud will not Be Chosen Because of Auditors of new companies. The research hypothesis is:

H5: Rationalization (AUDCHAN) has positive effect on fraudulent financial reporting

\section{Capability on Fraudulent Financial Reporting}

Capability is personal trait and ability that can carry out fraudulent functions and indeed can occur (Wolfe and Hermanson, 2004). Capability in this study is the level of capacity and strength of a person who influences fraudulent financial reporting in the company. In this study, the proportion of independent board members (IND) will be used as a proxy for capability. Percentage of independent board members (IND) has an effect on fraudulent financial reporting (Amara et al., 2013).

According to Wolfe and Hermanson (2004) stated that Capability position someone or function in the organization in terms of ability or capacity and how much power someone has committed fraud in the environment company with make or use opportunity to fraud. This statement is proven from the results of the study Pardosi (2015) which states that capability (capability) has a positive and significant effect on fraudulent financial reporting.

Fraud behavior can be minimized by a good and efficient monitoring mechanism. An independent board can increase effectiveness in corporate supervision. Beasley (1996) states clearly that the entry of commissioners from outside the company is believed to increase the effectiveness of the supervisory board in overseeing management to prevent fraudulent financial reporting. this opinion is corroborated by the results of the study Pardosi (2015) which states that capability has a positive and significant effect on fraudulent financial reporting.

H6: Capability (IND) has negatively effect of fraudulent financial reporting

\section{METHODOLOGY}


This type of research was a correlational study in which researchers examine the important variables associated with the problem. Quantitative approach was used because the data was obtained in the form of numbers and analysis by using statistics. In this study, hypothesis that aims to analyze the influence of financial ratios to fraudulent financial reporting was used.

The population of this research is Banking companies are included in the Indonesia Stock Exchange (IDX) for 6 years, from 2011-2016. The sample selection in this study uses purposive sampling as follows: (1) Banking companies listed on the Stock Exchange from 2011-2016, and (2) banking companies issue annual financial reports for each period of December 31, 2011-2016.

The election of a banking company population because banks that are financial actors and contribute to state revenues and are monitored and have strict regulations are often fraud. The sample of this study is secondary data annual report of companies that go public, in the banking sector with a period of 2011-2016.

\section{Operational Variables}

\section{Fraudulent Financial Reporting}

The dependent variable of this study is fraudulent financial reporting. Rezaee (2002), explains that fraudulent financial reporting occur starting from management earnings. Thus fraudulent financial reporting are proxied by management earnings as measured by a specific accrual model developed by (Molida, 2011). Analysis Method Testing the hypothesis used is a multiple linear regression model. Beaver and Engel models with the formula:

DACCit $=\beta O+\beta 1 D E B T+\beta 2 L D R+\beta 3 L D R+$ B4AUD + B5AUDCHAN + B6IND $+\varepsilon$ Information:

BO : Constant regression coefficient $ß 1,2,3,4,5,6$ : Regression coefficient of each proxy
DACCit: Discretionary accruals of companies i years $\mathrm{t}$

DEBT : Total Debt ratio per total asset

LDR : The ratio of short-term debt to total asset

ROA : Return on assets

AUD : Audit Quality Ratio

AUDCHAN: Auditor turnover ratio

IND : Ratio of Independent Commissioners

e : error

\section{External Pressure, Proxied by Debt (DEBT)}

External pressure is excessive incentive for management to meet requirements or expectations of third parties. Formula In this study, leverage is a proxy of external pressure. According to Amara et al., (2012) leverage is measured by comparing the total debt and total assets of the company. In this case, debt leverage is a proxy for external pressure measured by comparing total debt with the company's total assets (Amara et al., 2013).

\section{Financial Stability, Proxied by Liquidity (LDR)}

Financial stability is a financial condition of the company in a stable condition. When the company's financial condition is unstable, the risk of fraudulent financial reporting decreases. Liquidity is the company's ability to complete its short-term obligations. Financial stability in this study uses a proxy loan deposit ratio (LDR), this ratio is the ratio funds received by banks.

\section{Financial Targets, Proxied by Return On Assets (ROA)}

Return on assets (ROA), that is a measure of operational performance that is widely used to describe how efficient the assets have been used, ROA is used to assess the performance of managers who will later relate to bonuses (Skousen, 2009). One source of external pressure is the ability to repay debt (Skousen, 2009. So, that the leverage ratio will be a proxy of the company's external pressure. In this study using ROA by comparing profit 
with the total company assets (Amara et al., 2013).

\section{Ineffective Monitoring, Proxied by External} Audit Quality (AUD)

Ineffective monitoring is a situation where the company has an effective supervisory unit visit the company's management performance. Ineffective monitoring is proxied by a dummy variable with a company that is affiliated with a BIG4 public accounting firm with number 1 and a company that is not affiliated with a non-BIG4 public accounting firm is numbered 0 .

\section{Rationalization, Proxied by Change in Auditor (AUDCHAN)}

Changes to the auditor's part are the most difficult. This auditor's turnover calculation uses dummy variable with companies that make auditor changes given number 1 and number 0 for companies that do not make changes auditor for a period of 5 years according to the applicable ministerial regulation.

\section{Capability, Proxied by Independent Board of} Commissionners (IND)

The independent variable is the percentage of independent board members who have no funds management, share ownership or other relationships that might affect their ability to act independently. Independent boards are measured by the percentage of board of commissioners with the total number of commissioners (Lai, 2006).

\section{RESULTS AND DISCUSSIONS}

Based on the sample criteria used in this study, it was found that banking companies during 2011-2016 made 87 observations. From descriptive statistical results obtained the results are as follows:

Table 1. Descriptive Statistic

\begin{tabular}{llllll}
\hline & $\mathrm{N}$ & Minimum & Maximum & Mean & Std. Deviation \\
\hline DA & 87 & -.04596 & 1.23552 & .374924 & .13318430 \\
DEBT & 87 & .7516365 & .9398324 & .88712309 & .035475819 \\
LDR & 87 & .27706 & 1.01035 & .7691533 & .13808571 \\
ROA & 87 & -.05677 & .16396 & 0.147276 & .02028257 \\
IND & 87 & -00000 & 1.00000 & .5700192 & .11996191 \\
Valid N (list & 87 & & & & \\
wise) & & & & & \\
\hline
\end{tabular}

Source: Processed Secondary Data (2017)

Table 1. noted that from 87 observations, the results obtained for the earnings management variable (DA) had an average value 0.0374924 . The average earnings management of banking companies with a profit was $13.31 \%$. Variable ability of company to fulfil obligation (DEBT) had average value 0.887127309 . The company's ability to pay the company's debt in the amount of was 0.8871270309 which shows that 1 rupiah capital is able to bear liability 0.89 times. The liquidity ratio variable (LDR) had an average value of 0.7691533 . The company's ability to pay off the depositors withdrawals was 0.7691533 which shows 1 rupiah is able to bear the capital loan 0.77 times. ROA had an average value 0.0147276 . The ability of companies to generate profits by utilizing assets owned was 0.0147276 which shows capital rupiah 1 is able to generate profit 0.014 times. The proportion of independent board variable in the firm (IND) had an average value 0.5700192 which means the composition of the board of directors is $57 \%$ of the total board members in a company. 
Table 2. AUD Frequency

\begin{tabular}{lllll}
\hline & Frequency & Percentage & $\begin{array}{l}\text { Valid } \\
\text { Percentage }\end{array}$ & $\begin{array}{l}\text { Cumulative } \\
\text { Percentage }\end{array}$ \\
\hline Valid 0 & 28 & 32.2 & 32.2 & 32.2 \\
1 & 59 & 67.8 & 67.8 & 100.0 \\
Total & 87 & 100.0 & 100.0 & \\
\hline
\end{tabular}

Source: Processed Secondary Data (2017)

In the audit quality variable there is a minimum value of 0 and a maximum value of 1 . In a variable of value 0 , this means the company does not use the Big Four KAP services, while the value of 1 means the company uses the Big Four KAP services to audit the financial statements. The data table above shows that the number of banking companies that audited by Non-Big Four Firm were 28 companies and banking companies audited by KAP Big Four were 59 companies. This table also shows the percentage of banking companies audited by Non-Big Four Firm $32.2 \%$ while companies audited by KAP Big Four were $67.8 \%$. This shows that the majority of banking companies are audited by the Big Four KAP.

Table 3. AUDCHAN Frequency

\begin{tabular}{cllll}
\hline & Frequency & Percentage & $\begin{array}{l}\text { Valid } \\
\text { Percentage }\end{array}$ & $\begin{array}{l}\text { Cumulative } \\
\text { Percentage }\end{array}$ \\
\hline Valid 0 & 70 & 80.5 & 80.5 & 80.5 \\
1 & 17 & 19.5 & 19.5 & 100.0 \\
Total & 87 & 100.0 & 100.0 & \\
\hline
\end{tabular}

Source: Processed Secondary Data (2017)

The auditor change variable (AUD CHAN) has a minimum value 0 and the maximum value 1 . In this variable, the value 0 means that the company changed the auditor in 3 consecutive years, while the value 1 means that the company did not make the auditor change in 3 consecutive fiscal yearraw. Based on the data table, the number of banking companies changed auditors in 3 consecutive years were 70 companies and banking companies that do not make auditors change in 3 consecutive years were 17 companies. The table also shows the percentage of banking companies changed auditors in 3 years in a row by $80.5 \%$. While companies that do not make auditors turn in 3 years in a row was $19.5 \%$. This shows that the majority of banking companies change auditors in 3 consecutive years. Furthermore, for earnings management was calculated through several stages. First count NonDiscretionary Accrual obtained by regression equation:

DACCit $=\beta 0+\beta 1 D E B T+\beta 2 L D R+\beta 3 L D R+$ B4AUD + B5AUDCHAN + ß6IND $+\varepsilon$ to get the coefficient of independent variable. 
Tarmizi Achmad: Fraudulent Financial Reporting...

Table 4. Coeficient Independent Variables

\begin{tabular}{|c|c|c|c|c|c|}
\hline & $\begin{array}{l}\text { UnStandardied } \\
\text { Coeficient }\end{array}$ & & $\begin{array}{l}\text { Standardized } \\
\text { Coeficient }\end{array}$ & & \\
\hline Model & B & Std. Error & Beta & T & Sig. \\
\hline 1(Constant) & .038 & .055 & & .683 & .496 \\
\hline $\mathrm{CO}$ it & 1.962 & 2.926 & .092 & .671 & .504 \\
\hline LOAN it & -.039 & .277 & -.063 & -.502 & .617 \\
\hline NPA it & .429 & .244 & .351 & 1.760 & .082 \\
\hline Se1NPA it & .027 & .303 & .016 & 0.088 & .930 \\
\hline
\end{tabular}

Source: Processed Secondary Data (2017)

Table 5. shows that after the regression of these variables, coefficient of independent variables is then obtained, namely $\alpha 1=1.962$; $\alpha 2=-0.039 ; \alpha 3=0.429 ; \alpha 4=0.027$ which is then incorporated into the initial equation to obtain the value of Non-Discretionary Accrual (NDA). After obtaining the NDA value, derivative from the regression coefficient is processed with the following equation: DAit= TAit - NDAit.

Table 5. Determination Test Adjusted R2

\begin{tabular}{lllll}
\hline Model & $\mathrm{R}$ & R-Square & $\begin{array}{l}\text { Adjusted } \\
\text { Square }\end{array}$ & $\begin{array}{l}\text { Std Error of the } \\
\text { Estimate }\end{array}$ \\
\hline 1 & .632 & .400 & .310 & .29736 \\
\hline
\end{tabular}

Source: Processed Secondary Data (2017)

Determination test for adjusted coeficient R2 is used to determine how much the dependent variable is able to be explained by the independent variable. based on Table 5. it can be seen that the value of Adjusted $R$ Square is equal to 0.310 . this proves the independent variable were able to affect the dependent variable by $31 \%$. The statistical test shows the extent to which the influence of independent variables on the dependent variable individually. The results of statistical test:

Table 6. Test Results Hypothesis

\begin{tabular}{|c|c|c|c|c|c|c|c|}
\hline & $\begin{array}{l}\text { Un } \\
\text { Standardized }\end{array}$ & & $\begin{array}{l}\text { Standa } \\
\text { Coefici }\end{array}$ & & & & \\
\hline Model & B & $\begin{array}{l}\text { Std. } \\
\text { Error }\end{array}$ & Beta & $\mathrm{T}$ & Sig. & Sig/2 & Conclusion \\
\hline $\begin{array}{l}1 \\
\text { (Constant) }\end{array}$ & -.746 & .466 & & -1.599 & .117 & & \\
\hline LOG_DEBT & 12.035 & & .371 & 2.820 & .007 & .003 & Accepted \\
\hline LOG_LDR & -1.185 & 4.267 & -.149 & -1.274 & .209 & .004 & Accepted \\
\hline LOG ROA & .354 & .930 & .417 & 2.924 & .005 & .002 & Rejected \\
\hline AUD & -.140 & .121 & -172 & -1.410 & .165 & .082 & Rejected \\
\hline AUDCHAN & .042 & .109 & .044 & .386 & .702 & .351 & Rejected \\
\hline LOG IND & -1.705 & .592 & .367 & -2.882 & .006 & .003 & Accepted \\
\hline
\end{tabular}

Source: Processed Secondary Data (2017)

External Pressure (DEBT) Positive Affect the Fraudulent Financial Reporting.
Based on Table 6. above we can see that the variable incentive was proxied by having significance of Debt of 0.003 and 12.035 
illustrates that a company's capability in paying debt has a positive influence on fraudulent financial reporting. The more the ability of the company to pay large debts, the greater the fulfillment of debt will result in fraudulent financial reporting will also be higher. So, hypothesis 1 is accepted.

Management or company managers can commit fraudulent financial reporting if you see that external pressure in this case the ability to fulfill large obligations then tends to reduce debt and motivation to get high profits. This is sad with the results of the research Dechow et al., (2012) explained that the higher the company's debt then, the level of manipulation and fraud and the motivation to gain credit by fraud is getting higher. Furthermore, if the company has the opportunity, the company will prefer to conduct management earnings to show good performance to shareholders. The results of this study are different from the research of Amara et al., (2013) which proves debt does not affect the fraudulent financial reporting.

Based on Kirkor et al. (2014), a high debt structure is able to raise the level of fraudulent financial reporting, this is because the management of the company will making the risks that managers and investors have towards debt holders. This company's management is able to fraudulent financial reporting and all forms of financial reporting in order to meet the requirements in meeting their needs.

\section{Financial Stability (LDR) Negatively Affects the Fraudulent Financial Reporting.}

Table 6. explains that the financial stability variable shows coefficients of 0.004 and -1185 . Based on these results, it shows that liquidity in the form of fraudulent financial reporting has a negative impact if financial stability is disrupted due to the existence of economic situations that make the economic situation difficult for companies to pay all their debts. Company management must be under incentive and encouraged to commit fraud (Skousen et al., 2011). The results of are different from the research of Amara et al., (2013) which proves liquidity does not affect the fraudulent financial reporting.

The results of this study are in line with and supported by the research of Molida, (2011) which proves that financial stability has a significant effect on fraudulent financial reporting. The lower the Loan to Deposit (LDR) ratio, the higher in encouraging company management to carry out various ways of fraudulent financial reporting to prove and convince financial reporting users and shareholders that the company is in a good and healthy condition.

\section{Financial Targets (ROA) Have Negative Effect on the Fraudulent Financial Reporting.}

Table 6. shows that the financial target variables proxied by Return on Assets have coefficient values of 0.354 and 0.002 . based on this value, the financial target has a negative influence on fraudulent financial reporting, but the results are not significant, which means that hypothesis 3 is rejected.

Managers or company management are required to be able to run the company and show their best performance to be able to achieve the planned targets. ROA is a measure in assessing a company's performance to produce a company's net profit by using all its assets so that it shows how efficiently these assets are used by the company's management (Skousen et al., 2011). Thus the higher the value of return on assets, the greater the occurrence of fraudulent financial reporting carried out. The results of this study in accordance with the results of research conducted by Farber and Lee (2011) prove that indeed companies with high levels of ROA have a tendency to fraud financial reporting when compared with companies that have a low rate of return on assets. 


\section{Ineffective Mentoring (External Audit Quality) Negatively Affects the Fraudulent Financial Reporting.}

Based on the results of data processing presented in Table 4.6 shows that variable effective monitoring has a significance value of 0.082 with a coefficient of -0.140 . Thus it shows that there is no significant effect between ineffective monitoring of fraudulent financial reporting, but the relationship between these variables is negative. Then it can be concluded that hypothesis 4 is rejected.

Most people have the view that a company with a large-scale public accounting firm has a high audit quality and no fraud. this is not correct because companies with affiliations with bear accountants are not always proven to handle management earnings and fraudulent financial reporting. This is probably due to the management of the company's business showing that the performance is good for the shareholders but ignores the existence of its public accounting firm, BIG4 public accounting firm. This research is in line with the results of research conducted by Luhgianto (2008), Molida (2011) and Pardosi, (2015) which also shows that the ineffective monitoring does not affect fraudulent financial reporting.

\section{Rationalization (Change in Auditor) Positive Affects the Fraudulent Financial Reporting.}

In Table 6 . the results of data analysis show a significance value of 0.351 and a coefficient +0.042 . It can be concluded that the quality of internal audit does not have a significant effect on fraudulent financial reporting and has a positive relationship between the quality of external auditors on fraudulent financial reporting. So, it can be concluded that hypothesis 5 which states that the external auditor has an effect on fraudulent financial reporting is rejected.

Companies with high quantities in auditor turnover have a tendency to fraudulent financial reporting, fraudulent financial reporting carried out by the company are not expected to be detected by the successor company or called a new auditor. However, the results of this study do not prove influential. This is likely due to changes made by the company only in order to comply with ministerial regulations. The results of this study are in line with the results of research conducted by Molida (2011) and Pardosi, (2015) which states that Rationalization have no significant effect on fraudulent financial reporting.

\section{Capability (Independent Board of Commissionners) Negatively Affects the Fraudulent Financial Reporting}

Based on the results of testing the data analysis presented in table 4.6 shows that the significance value of 0.003 and the coefficient value of -1.705 shows that capability by proxy the proportion of independent commissioners has a significant effect on fraudulent financial reporting and has a negative relationship. This means that the higher the percentage of independent commissioners in the company, the lower the fraudulent financial reporting that occur. So it can be concluded that the hypothesis that the board of commissioners percentage has a significant effect on fraudulent financial reporting is proven and Hypothesis 6 is accepted.

Financial report fraud can be taken preventive steps and reduced by adding independent board of commissioners to a company, especially banks. The existence of a board of commissioners will make the effectiveness of the company under more stringent and independent supervision without intervention from any party. Conversely, if the board of directors who are not independent are vulnerable to be influenced to commit fraudulent reports such as earnings management. Beasley (996) explained that commissioners originating not from within the company can actually increase the level of effectiveness of the independent board in monitoring for conduct more optimal supervision and were able to prevent 
fraudulent financial reporting. The results of this study are supported and in line with the results of the study of Lennox and Pittman (2010) and Pardosi, (2015) which states that the proportion of independent commissioners proxy capability influences fraudulent financial reporting.

\section{CONCLUSION}

Based on the results of the discussion and discussion above, it can be concluded that the external pressure that is proxyed with Debt has a positive significant effect on fraudulent financial reporting. Financial stability proxied by LDR negatively impacts fraudulent financial reporting. Financial targets are proxied by ROA positive effects on incorrect financial reporting. Ineffective monitoring that is proxied with the external audit quality of the AUD cannot affect on fraudulent financial reporting. The rationalization driven by auditor changes had no significant effect on the incorrect financial statements. Abilities driven by the number of independent firm (IND) boards negatively affected fraudulent financial reporting.

COSO sponsored this study, Fraudulent Financial Reporting: 1998-2010, to provide comprehensive analysis of investigative fraudulent financial reporting occurrences by the U.S. Securities and Exchange Commission (SEC) between January 1998 and December 2007. This study also updates our understanding of fraud since analysis. The Fraud triangle is a diamond fraud in factors that cause fraudulent financial Reporting (Lou and Wang, 2009). The limitation of this study is to use financial data from the banking company's annual report. Subsequent research can explore non-financial factors that are able to analyze more deeply, so that more detail in knowing the causes of fraudulent financial reporting can occur outside of financial factors.

The recommendation for further research is to be able to develop research by adding fraudulent elements such as arrogance from the pentagon fraud or using other variables of other proxies in order to better know the factors that influence fraudulent financial reporting.

\section{REFERENCES}

Abbasi, A., et al. (2012). Metafraud: a metalearning framework for detecting financial fraud. Mis Quarterly, 12931327.

Amara, I., et al. (2013). Detection of Fraud in Financial Statement: French Companies as a Case Study. International Journal of Academic Research in Accounting, Finance and Management Sciences. Vol.3.

Albrecht, C., et al. (2010). The Relationship between South Korean Chaebols and Fraud. Managerial Auditing Journal. Vol.33 (3).

Association of Certified Fraud Examiners. (2016). Report to the Nations on Occupational Fraud and Abuse: 2016 Global Fraud Study. Association of Certified Fraud Examiners.

Baik, B. O. K., et al. (2011). CEO ability and management earnings forecasts. Contemporary Accounting Research, 28(5), 1645-1668.

Bank Indonesia Regulation Number 12/19 / PBI / 2010 concerning Statutory Reserves for Commercial Banks At Bank Indonesia in Rupiah and Foreign Exchange

Beasley, M. (1996). An Empirical Analysis of The Relation Between The Board of Directors of Fraud's Composition and Financial Statement. The Accounting Review. 71 (4): 443-465.

Chye Koh, H., \& Woo, E. S. (1998). The expectation gap in auditing. Managerial auditing journal, 13(3), 147-154. 
DeAngelo, L. E. (1981). Auditor size and audit quality. Journal of accounting and economics, 3(3), 183-199.

Dechow, P., Sloan, R., Sweeney, A. (2012). Detecting Earnings Management. The Accounting Review. Volume 70.

Dorminey, J., et al. (2010). The Evaluation of Fraud Theory. American Accounting Association Annual Meeting. Denver.

Europe, R. A. N. D. (2012). Ernst \& Young LLP. National evaluation of the Department of Health's Integrated Care Pilots. London: Department of Health.

Kirkos, E., et al. (2007). Data mining techniques for the detection of fraudulent financial statements. Expert systems with applications, 32(4), 995-1003.

Kirkos, E., et al. (2014). Data Mining Techniques for The Detection of Fraudulent Financial Statements. Expert Systems with Applications. 32 (4): 995-103.

Lai, L. H. Y. (2006). Are independent directors effective in lowering earnings management in China? (Doctoral dissertation, Texas A\&M University).

Lennox, C., Pittman, J. (2010). Big Five Audits and Accounting Fraud. Contemporary Accounting Research.Vol27, No1: 209247.

Lou, I., \& Wang, W. (2009). Fraud risk factor of the fraud triangle assessing the likelihood of fraudulent financial reporting. Journal of business \& economics research, 7(2), 63-78.

Luhgiatno. (2010). Effect Analysis Audit Quality on Earnings Management Companies that Conduct Study on IPO in Indonesia. Focus Economics. Vol. 5. No.2. December 2010.

Molida, Resti. (2011). Effect of Financial Stability, Personal Financial Need and ineffective monitoring on Financial Statement Fraud in Perspective.
Otley, D. (1994). Management control in contemporary organizations: towards a wider framework. Management accounting research, 5(3-4), 289-299.

Owolabi, S. A. (2010). Fraud and fraudulent practices in Nigeria banking industry. African Research Review, 4(3).

Pardosi, R. W. (2015). Diamond fraud analysis in detecting fraudulent financial statements in manufacturing companies in Indonesia using the fraud score model (2010-2013) (Doctoral dissertation, Faculty of Economics and Business).

Rahmanti, M. M. (2013). Detection of Financial Report Fraud Through Risk Factors of Pressure and Opportunity. Undergraduate Thesis Program, Faculty of Economics and Business, Diponegoro University.

Rasha, K. \& Andrew H. (2012). The New Fraud Triangle. Journal of Emerging Trends in Economics and Management Sciences.Vol.3 (3).

Ravisankar, P., Ravi, V., Rao, G. R., \& Bose, I. (2011). Detection of financial statement fraud and feature selection using data mining techniques. Decision Support Systems, 50(2), 491-500.

Rezaee, Z. (2002). Financial Statement Fraud: Motives, Methods. Cases and Detection. Dissertation. com: Florida.

Rukmawati, A. D., \& CHARIRI, A. (2011). Perception of Managers and External Auditors Regarding the Effectiveness of the Method of Detecting and Preventing Financial Fraud (Doctoral dissertation), Diponegoro University.

Skousen, C. J., Smith, K. R., \& Wright, C. J. (2009). Detecting and predicting financial statement fraud: The effectiveness of the fraud triangle and SAS No. 99. In Corporate governance and firm performance (pp. 53-81). Emerald Group Publishing Limited. 
Skousen, J.C., Wright, J.C., Smith Kevin, R. (2011), Detecting and Predicting Financial Statement Fraud: The Effectiveness of The Fraud Triangle and SAS No. 99: Advances in Financial Economics, Vol. 13.

Smaili, N., Labelle, R., Stolowy, H. (2009). La publication d'une Information Financière Non Conforme à la loi et aux normes: Déterminants et Conséquences. Comptabilité Contrôle - Audit, $\mathrm{n}^{\circ} 15$ (1), 2009, p. 159-198.

Spathis, C. T. (2002). Detecting false financial statements using published data: some evidence from
Greece. Managerial

Auditing Journal, 17(4), 179-191.

Wolfe, D.T. \& Hermanson, D.R. (2004). The Fraud Diamond: Considering the Four Elements of Fraud: The Certified Public Accountants (CPA) Journal.

Zhang, L., \& Guan, Y. (2008, June). Detecting click fraud in pay-per-click streams of online advertising networks. In Distributed Computing Systems, 2008. ICDCS'08. The 28th International Conference on (pp. 77-84). IEEE.Albrecht, C., Turnbull, C., Zhang, Y. \& Skousen, C.J. (2010). The Relationship between South Korean Chaebols and Fraud. Managerial Auditing Journal. Vol.33 (3). 
Marina 